\title{
Association of inflammatory gene polymorphisms with mechanical heart valve reoperation
}

\author{
Kyung Eun Lee ${ }^{1 \dagger}$, Joo Hee Kim²,3†, Jee Eun Chung ${ }^{3}$, Gwan Yung Lee ${ }^{3}$, Yoon Jeong Cho ${ }^{1}$, Byung Chul Chang ${ }^{*}$ \\ and Hye Sun Gwak ${ }^{3 *}$
}

\begin{abstract}
Background: Various complications lead to reoperation in patients who undergo prosthetic valve replacement where inflammatory process could be involved. The goals of this study were to identify risk factors that correlate with reoperation in patients with prosthetic heart valves and to investigate the relationship between reoperation and inflammatory gene polymorphisms.

Results: The study included 228 patients from the EwhA-Severance Treatment Group of Warfarin. Single nucleotide polymorphisms of c-reactive protein (CRP), interferon-gamma, interleukin 1 beta, interleukin 6, interleukin 10, transforming growth factor beta 1, and tumor necrosis factor genes were genotyped by means of SNaPshot and TaqMan assays. Thirty-nine patients (17.1\%) underwent more than one heart valve operation. A threefold increased risk for heart valve reoperation was evident in homozygous variant-type (TT) carriers as compared with ancestral allele carriers of CRP rs 1205. Logistic regression analysis revealed that CRP rs1205 (OR 2.68, $95 \% \mathrm{Cl} 1.22-5.90, p=0.014$ ), valve position (mitral valve OR 2.80, $95 \% \mathrm{Cl} 1.01-7.80, \mathrm{p}=0.048$; tricuspid valve $\mathrm{OR} 9.24,95 \% \mathrm{Cl}$ 2.46-34.70, $\mathrm{p}=0.001$; reference: aortic valve) and time after first operation (OR 1.13, $95 \% \mathrm{Cl} 1.06-1.20, \mathrm{p}<0.001)$ affected the risk of reoperation.
\end{abstract}

Conclusions: Inflammatory gene polymorphisms could be a possible marker of risk for reoperation in patients with prosthetic heart valve surgery.

Keywords: Inflammatory gene polymorphisms, Mechanical heart valve, Reoperation, C-reactive protein

\section{Background}

Currently, approximately 280,000 prosthetic heart valves are implanted worldwide every year. Of these, about $50 \%$ are mechanical valves (Pibarot and Dumesnil 2009). However, prosthetic heart valves may require one or more reoperations. About $10 \%$ of the patients with an aortic or mitral mechanical valve usually undergo

\footnotetext{
*Correspondence: bcchang@yuhs.ac; hsgwak@ewha.ac.kr

${ }^{\dagger}$ Kyung Eun Lee and Joo Hee Kim contributed equally to this study

${ }^{3}$ Division of Life and Pharmaceutical Sciences, College of Pharmacy, Ewha Womans University, 11-1 Daehyun-Dong Seodaemun-Gu, Seoul 03760, Korea

${ }^{4}$ Department of Thoracic and Cardiovascular Surgery, Yonsei University Medical Center, 50-1 Yonsei-Ro Seodaemun-Gu, Seoul 03722, Korea Full list of author information is available at the end of the article
}

reoperation 10 years after the initial surgical procedure (Frank et al. 1995). Reoperations are more complicated than the initial valve operations, and are associated with higher mortality rates with mechanical valves than with tissue valves (Jones et al. 2001).

Various complications lead to reoperation in patients who undergo prosthetic valve replacement, the most frequent being obstructive valve thrombosis and pannus development (Rizzoli et al. 1999). Valve thrombosis occurs when a thrombus is attached to or is near a prosthetic heart valve, obstructing blood flow or causing valve regurgitation. Other reasons for reoperation include failure of previous valve repair, paravalvular leakage, infective or non-infective endocarditis, and prosthetic valve 
dysfunction due to fibrous tissue ingrowth and calcification (Piehler et al. 1995).

The infiltration of activated macrophages and T-cells, as well as cytokine release, has been described in human stenotic aortic valves. Previous studies have shown that cardiac valve calcification and ossification also involve an inflammatory process. This process includes the release of cytokines, chemokines, growth factors, and hydrolytic enzymes that contribute to angiogenesis, atherosclerotic plaque growth, and ossification of the valve (Helske et al. 2007). Although inflammation is assumed to be a factor in the occurrence of adverse complications after heart valve replacement (Sinning et al. 2012), studies to address the role of inflammatory gene polymorphisms related to valve surgery have been scarce. Therefore, this study was designed to determine the risk factors associated with reoperation in patients with prosthetic heart valves, with an emphasis on cytokine genetic polymorphisms, considering their role in inflammation-related prosthetic valve dysfunction.

\section{Methods}

\section{Study population}

The study population consisted of 228 patients from the EwhA-Severance Treatment (EAST) Group of Warfarin who underwent mechanical heart valve replacement between January 1982 and December 2009 at Severance Cardiovascular Hospital of Yonsei University College of Medicine in Seoul, Korea. EAST cohort is comprised of patients who had warfarin therapy after a mechanical heart valve replacement, and who did not have any evidence of hepatic or renal impairment. Patients were followed up continuously at the Severance Cardiovascular Hospital of Yonsei University Medical Center outpatient clinic. We reviewed the patients' paper charts and electronic medical records from June 1983 through May 2013 and collected data on age, age at the time of operation, gender, time after the first heart valve surgery, position of the valve prosthesis, INR, and comorbidities. Blood samples used for genotyping were collected from the 228 patients during regular outpatient clinic visits. The study protocol was approved by the institutional review board and Ethics Committee of Severance Hospital (IRB No. 2009-4-0283), and informed consent was obtained from all patients prior to their participation in the study.

\section{Genotyping}

Genomic DNA of study patients was prepared from ethylenediaminetetraacetic acid blood samples using a QIAamp DNA Blood Mini Kit (Qiagen, Hilden, Germany) according to standard procedures recommended by the manufacturer. We selected single nucleotide polymorphisms of C-reactive protein $(C R P)$, interferon-gamma (IFNG), interleukin-1beta (IL1B), interleukin-6 (IL6), interleukin-10 (IL10), transforming growth factor beta-1 (TGFB1), and tumor necrosis factor (TNFA) based on previously published data regarding genetic polymorphisms in inflammation-related diseases, including coronary artery disease and myocardial infarction (Table 1; Cruz et al. 2013; Wang et al. 2015; Garg et al. 2013; Iacoviello et al. 2005). Genotyping was conducted using SNaPshot or TaqMan assays.

\section{Statistical analyses}

Univariate and multivariate analyses were performed to determine the association of these genotypes with the recurrence of heart valve operations. The Chi square test was used to compare categorical variables; if the expected frequencies were less than 5 in any one cell, we used Fisher's exact test to obtain a $\mathrm{p}$ value. For continuous variables, an independent sample $t$ test was performed, and their approximation to normality was judged by means of the Shapiro-Wilk W test. Depending on the distribution, either the $t$ test or the Mann-Whitney test was used for analysis of the variables. A logistic regression model was used to investigate the factors that independently affected the number of operations. All analyses were performed with the SPSS Statistics version 20 software (IBM, New York City, NY, USA). Differences with a p value of less than 0.05 were considered statistically significant.

\section{Results}

A total of 228 patients who had undergone heart valve replacements were followed-up from June 1983 to May 2013. Of these patients, 39 (17.1\%) underwent more than one heart valve operation. The reasons for reoperations were failure of the previous repair $(n=14)$, valve dysfunction $(\mathrm{n}=17)$, periprosthetic leak $(\mathrm{n}=5)$, valve thrombosis $(\mathrm{n}=1)$, endocarditis $(\mathrm{n}=1)$, and unknown $(\mathrm{n}=1)$. There was a significant difference between the patients with and those without reoperation in the average length of time after the first surgery $(\mathrm{p}<0.001)$. More female than male patients had undergone reoperation ( 20.8 vs. $10.1 \%, p=0.042$ ). Valve positions were a statistically significant predictor of reoperation, and tricuspid valve surgery posed the highest risk for reoperation. There were no significant differences between patients with and those without reoperation in terms of age, age at operation, percentage of time in the therapeutic range on warfarin, and comorbidities. Table 2 shows the demographic characteristics with regard to the number of heart valve operations.

We evaluated the effects on reoperation of eight genetic variants of seven inflammatory mediator genes in 228 study patients. These genotypes included IL1B rs16944, IL6 rs1800796, IL10 rs1800871, IL10 rs1800896, IFNG 
Table 1 SNP information

\begin{tabular}{|c|c|c|c|c|}
\hline Gene rs number & Global minor allele frequency & Functional consequence & Direction & Primer sequence \\
\hline \multirow[t]{3}{*}{ ILIB rs16944 } & \multirow[t]{3}{*}{$G=0.4906$} & \multirow[t]{3}{*}{ Upstream variant $2 \mathrm{~KB}$} & $\mathrm{~F}^{\mathrm{a}}$ & CCAGCCAAGAAAGGTCAAT \\
\hline & & & $R^{b}$ & GAAGAGGTTTGGTATCTGCCA \\
\hline & & & $G^{c}$ & CAATTGACAGAGAGCTCC \\
\hline \multirow[t]{3}{*}{ IL 10 rs1800871 } & \multirow[t]{3}{*}{$A=0.4347$} & \multirow[t]{3}{*}{ Upstream variant $2 \mathrm{~KB}$} & $\mathrm{~F}$ & GAAACCAAATTCTCAGTTGGC \\
\hline & & & $\mathrm{R}$ & ATGACCCCTACCGTCTCTATTT \\
\hline & & & G & TGGTGTACCCTTGTACAGGTGATGTAA \\
\hline \multirow[t]{3}{*}{ IL10 rs1800896 } & \multirow[t]{3}{*}{$C=0.2722$} & \multirow[t]{3}{*}{ Intron variant } & $\mathrm{F}$ & ACACACACACAAATCCAAG \\
\hline & & & $\mathrm{R}$ & ATAGGAGGTCCCTTACTTTCCTC \\
\hline & & & G & ТССТСТTACСТATСССТАСТTСССС \\
\hline \multirow[t]{3}{*}{ IFNG rs2430561 } & \multirow[t]{3}{*}{$A=0.2802$} & \multirow[t]{3}{*}{ Intron variant } & $\mathrm{F}$ & ATATTCAGACATTCACAATTGATT \\
\hline & & & $\mathrm{R}$ & TATTATACGAGCTTTAAAAGATAGTTCC \\
\hline & & & G & TTTATXCTTACAACACAAAATCAAATC \\
\hline \multirow[t]{3}{*}{ TNFA rs 1800629} & \multirow[t]{3}{*}{$A=0.0903$} & \multirow[t]{3}{*}{ Upstream variant $2 \mathrm{~KB}$} & $\mathrm{~F}$ & AGAAGGAAACAGACCACAGAC \\
\hline & & & $\mathrm{R}$ & GGGAAAGAATCATTCAACCA \\
\hline & & & G & TAGGTTTTGAGGGGCATG \\
\hline \multirow[t]{3}{*}{ TGFB1 rs 1800470} & \multirow[t]{3}{*}{$G=0.4547$} & \multirow[t]{3}{*}{ Missense } & $\mathrm{F}$ & GCCCATCTAGGTTATTTCC \\
\hline & & & R & TGCCAGTCACTTCCTACC \\
\hline & & & G & AGCAGCGGTAGCAGCAGC \\
\hline \multirow[t]{3}{*}{ CRP rs 1205} & \multirow[t]{3}{*}{$\mathrm{T}=0.3383$} & \multirow[t]{3}{*}{ UTR variant 3 prime } & $\mathrm{F}$ & ATCTTYTTGCTGCTGGATTTC \\
\hline & & & $\mathrm{R}$ & TTGTTTGTCAATCCCTTGG \\
\hline & & & G & CTTGTTTGCCACATGGWGAGAGACT \\
\hline
\end{tabular}

\footnotetext{
a Forward primer

b Reverse primer

c Genotyping primer
}

rs2430561, TNFA rs1800629, TGFB1 rs1800470, and $C R P$ rs1205. The observed genotype frequencies were consistent with the Hardy-Weinberg equilibrium for all SNPs. A statistically significant association between genotypes and reoperation was found for IL10 rs1800896 and CRP rs1205. We observed a 3.3-fold increased risk for reoperation of the heart valve in homozygous varianttype $(T T)$ carriers as compared with ancestral carriers of CRP rs1205. Two patients who carried CC allele of IL10 rs1800896 underwent reoperation, but there were no CC allele carriers in the single operation group. In contrast, $20.8 \%$ of patients who carried the T allele underwent reoperation. Table 3 shows the association between reoperation and the grouped genotypes.

After adjustment for variables that were statistically significant on the univariate analyses (i.e., gender, time after first operation, body mass index, valve position, and $C R P$ rs1205), the binary logistic regression analysis confirmed that time after first operation, valve position, and CRP rs1205 were significantly associated with reoperation (Table 4). Patients with tricuspid valve replacements were at 9.2-fold increased risk for reoperation, compared with those who underwent aortic valve replacements. Variant-type homozygote carriers of CRP rs1205 showed a statistically higher risk for reoperation than did the ancestral allele carriers $(\mathrm{p}=0.014$, adjusted OR 2.684, 95 \% CI 1.222-5.895).

Clinical characteristics of minor allele (TT) carriers of rs 1205 were 55 females $(66.3 \%, \mathrm{p}=0.598)$, younger age groups ( $<65$ years; $57.8 \%, \mathrm{p}=0.466$ ), mitral valve prosthesis $(50.6 \%)$, and with atrial fibrillation $(61.4 \%, \mathrm{p}=0.070)$. However, rs1205 variant was not significantly associated with clinical demographics except for reoperation.

Subgroup analyses were conducted to compare the reoperation rate in relation to the genotypes in patients who underwent mitral valve operations. The first heart valve operation in 113 patients involved the mitral valve, and 23 of these patients underwent reoperation. The presence of TGFB1 rs1800470 and CRP rs1205 polymorphisms was statistically significant with respect to mitral valve reoperations $(p=0.043$ and $p=0.031$, respectively). In addition, patients with the variant-type allele (A) of TGFB1 rs1800470 were at lower risk for reoperation compared with those who had ancestral homozygous alleles (G) (OR 0.377, 95 \% CI 0.144-0.987; Table 5). Consistent with the whole-population analysis, the risk of reoperation was increased in the TT carriers of CRP rs1205 (OR 2.734, 95 \% CI 1.073-6.969). 
Table 2 Demographic characteristics and number of heart valve operations

\begin{tabular}{|c|c|c|c|}
\hline \multirow[t]{2}{*}{ Characteristics } & \multicolumn{2}{|c|}{$\begin{array}{l}\text { Patient number or } \\
\text { mean } \pm \text { SD } \\
\text { Number of heart } \\
\text { valve operations }\end{array}$} & \multirow[t]{2}{*}{$\mathrm{p}$ value } \\
\hline & 1 & $\geq 2$ & \\
\hline Operation & 189 & 39 & \\
\hline Time after first operation (years) & $16 \pm 7$ & $23 \pm 9$ & 0.002 \\
\hline Age & $58 \pm 10$ & $57 \pm 10$ & 0.333 \\
\hline Age at first operation & $43 \pm 11$ & $45 \pm 11$ & 0.476 \\
\hline \multicolumn{4}{|l|}{ Gender } \\
\hline Male & 71 & 8 & 0.042 \\
\hline Female & 118 & 31 & \\
\hline Body mass index $\left(\mathrm{kg} / \mathrm{m}^{2}\right)$ & $22.84 \pm 2.77$ & $21.70 \pm 2.99$ & 0.023 \\
\hline \multicolumn{4}{|c|}{ Time in therapeutic range on warfarin } \\
\hline$<60 \%$ & 132 & 27 & 0.866 \\
\hline$\geq 60 \%$ & 55 & 12 & \\
\hline \multicolumn{4}{|l|}{ Valve position } \\
\hline Aortic & 52 & 5 & 0.001 \\
\hline Mitral & 90 & 23 & \\
\hline Double ${ }^{a}$ & 38 & 3 & \\
\hline Tricuspid $^{b}$ & 9 & 8 & \\
\hline \multicolumn{4}{|l|}{ Comorbidity } \\
\hline \multicolumn{4}{|l|}{ Hypertension } \\
\hline Absent & 139 & 30 & 0.661 \\
\hline Present & 50 & 9 & \\
\hline \multicolumn{4}{|l|}{ Diabetes mellitus } \\
\hline Absent & 174 & 34 & 0.326 \\
\hline Present & 15 & 5 & \\
\hline \multicolumn{4}{|l|}{ Congestive heart failure } \\
\hline Absent & 146 & 34 & 0.166 \\
\hline Present & 43 & 5 & \\
\hline \multicolumn{4}{|l|}{ Atrial fibrillation } \\
\hline Absent & 85 & 13 & 0.181 \\
\hline Present & 104 & 26 & \\
\hline \multicolumn{4}{|l|}{ Myocardial infarction } \\
\hline Absent & 84 & 17 & 1.000 \\
\hline Present & 105 & 22 & \\
\hline
\end{tabular}

${ }^{a}$ Aortic plus mitral valve

${ }^{\text {b }}$ Any valve replacements including tricuspid valve

\section{Discussion}

Advances in surgical techniques and progress in valve design and materials have improved the clinical outcomes of patients with heart valve diseases. However, the placement of prosthetic heart valves often requires one or more reoperations. Several studies have sought to identify factors related to the occurrence of prosthetic valve dysfunction. Although the main causes may vary with patient demographic characteristics, disease progression
Table 3 Association between reoperation and grouped genotypes of inflammatory mediators

\begin{tabular}{|c|c|c|c|c|}
\hline \multirow[t]{2}{*}{$\begin{array}{l}\text { Gene polymorphisms } \\
\text { (minor allele frequency) }\end{array}$} & \multicolumn{2}{|c|}{$\begin{array}{l}\text { Patient } \\
\text { number } \\
\text { Number } \\
\text { of heart valve } \\
\text { operations }\end{array}$} & \multirow[t]{2}{*}{ p value } & \multirow[t]{2}{*}{ OR (95 \% Cl) } \\
\hline & 1 & $\geq 2$ & & \\
\hline \multicolumn{5}{|l|}{ ILIB rs16944 (0.43) } \\
\hline $\mathrm{AA}, \mathrm{AG}$ & 126 & 27 & 0.756 & 1 \\
\hline GG & 63 & 12 & & $0.889(0.422-1.871)$ \\
\hline \multicolumn{5}{|l|}{ IL6 rs1800796 (0.27) } \\
\hline GG & 15 & 2 & 0.744 & 1 \\
\hline GC, CC & 172 & 37 & & $1.613(0.534-7.359)$ \\
\hline \multicolumn{5}{|l|}{ IL10 rs1800871 (0.29) } \\
\hline $\mathrm{AA}, \mathrm{AG}$ & 170 & 37 & 0.743 & 1 \\
\hline GG & 15 & 2 & & $0.613(0.134-2.794)$ \\
\hline \multicolumn{5}{|l|}{ IL 10 rs1800896 (0.07) } \\
\hline $\mathrm{TT}, \mathrm{TC}$ & 184 & 37 & 0.030 & \\
\hline $\mathrm{CC}$ & 0 & 2 & & \\
\hline \multicolumn{5}{|l|}{ IFNG rs2430561 (0.20) } \\
\hline $\mathrm{AA}$ & 154 & 31 & 0.574 & 1 \\
\hline $\mathrm{AT}, \mathrm{TT}$ & 31 & 8 & & $1.282(0.538-3.053)$ \\
\hline \multicolumn{5}{|l|}{ TNFA rs1800629 (0.04) } \\
\hline GG & 173 & 37 & 0.548 & 1 \\
\hline $\mathrm{GA}, \mathrm{AA}$ & 16 & 2 & & $0.584(0.129-2.652)$ \\
\hline \multicolumn{5}{|l|}{ TGFB1 rs1800470 (0.47) } \\
\hline $\mathrm{GG}, \mathrm{GA}$ & 145 & 29 & 0.584 & 1 \\
\hline $\mathrm{AA}$ & 40 & 10 & & $1.250(0.562-2.780)$ \\
\hline \multicolumn{5}{|l|}{ CRP rs1205 (0.40) } \\
\hline $\mathrm{CC}, \mathrm{CT}$ & 129 & 15 & 0.001 & 1 \\
\hline TT & 60 & 23 & & $3.297(1.606-6.766)$ \\
\hline
\end{tabular}

$O R$ odds ratio, $C I$ confidence interval, ILIB interleukin-1 beta, IL6 interleukin- 6 , IL10 interleukin-10, INFG interferon-gamma, TNFA: tumor necrosis factor alpha, TGFB1: transforming growth factor-beta 1, CRP: C-reactive protein

a Odds ratio was not calculated due to no patients in certain group

as well as prosthesis type, model, and implantation sites were found to be influential factors (Aydin and Yapici 2013; Weerasinghe et al. 1999; Chan et al. 2011). In this study, we focused on genetic risk factors to investigate the association of gene polymorphisms of inflammatory mediators with reoperation after prosthetic heart valve placement.

As has been noted by previous researchers, time after the initial operation also affected the risk of reoperation in our study patients (Rahimtoola 2010; Khan et al. 2001). In addition, based on the results of our univariate analysis, gender, body mass index, and valve position were found to correlate with the risk for reoperation.

Conflicting results have been reported regarding the effect of gender on the risk of valve surgery (Lytle et al. 
Table 4 Results of logistic regression analysis

\begin{tabular}{lll}
\hline Variables & $\begin{array}{l}\text { Adjusted odds ratio } \\
(\mathbf{9 5} \% \mathbf{C l})\end{array}$ & p value \\
\hline $\begin{array}{l}\text { Gender } \\
\text { Male }\end{array}$ & 1 & 0.179 \\
$\quad$ Female & $1.970(0.732-5.303)$ & \\
$\begin{array}{l}\text { Time after first operation } \\
\text { (year) }\end{array}$ & $1.129(1.063-1.199)$ & $<0.001$ \\
Body mass index $\left(\mathrm{kg} / \mathrm{m}^{2}\right)$ & $0.911(0.765-1.086)$ & 0.300 \\
Valve position & & \\
$\quad$ Aortic & 1 & 0.048 \\
$\quad$ Mitral & $2.804(1.009-7.796)$ & 0.796 \\
Double & $0.821(0.185-3.648)$ & 0.001 \\
Tricuspid & $9.244(2.463-34.695)$ & 0.014 \\
CRP rs1205 & & \\
CC, CT & 1 & \\
TT & $2.684(1.222-5.895)$ & \\
\hline
\end{tabular}

The odds ratio was adjusted for gender, time after first operation, body mass index, valve position, and CRP rs 1205

1986; Cohn et al. 1993). However, it is known that management and outcomes of valvular surgery can differ between men and women owing to differences in pathophysiology and body size (Redberg and Schiller 2004).

Consistent with previous findings, valve position affected risk of reoperation, showing highest risk in tricuspid valve replacement possibly because of the relatively high incidence of thrombosis or pannus ingrowth (Jones et al. 2001).

Although body weight has been shown to be associated with inflammation in previous studies, we found the reverse trend in our study (Fogarty et al. 2008; Nicklas et al. 2004). Obesity was not found to be a risk factor for adverse outcomes after valve surgery in other studies; however, our study confirmed that body mass index was associated with reoperation when analyzed as a continuous variable ( $\mathrm{p}=0.023$ ) but not as a categorical variable using a cutoff of $25 \mathrm{~kg} / \mathrm{m}^{2}$ ( $\mathrm{p}=0.069$ ) (Allama et al. 2013). An absolute comparison cannot be made between our results and previous studies because the average body mass index of our patients in both groups was within normal range (20.0$24.9 \mathrm{~kg} / \mathrm{m}^{2}$ ) and was rather lower on average in our study group as a whole $\left(\right.$ mean $\left.=22.7 \pm 2.8 \mathrm{~kg} / \mathrm{m}^{2}\right)$.

Insufficient anticoagulation or fluctuations in INR values within the therapeutic range can cause obstructive valve dysfunction. Therefore, we evaluated the effects of time to therapeutic range on the need for reoperation. A TTR cutoff value of $60 \%$ was used based on previous studies in which patients with a TTR below 55-60\% had higher mortality and a higher incidence of bleeding (White et al. 2007). However, our results did not indicate that TTR was a predictor of reoperation $(p=0.866)$.
Table 5 Subgroup analysis of patients with mitral valve operation

\begin{tabular}{|c|c|c|c|c|}
\hline \multirow[t]{2}{*}{$\begin{array}{l}\text { Gene polymor- } \\
\text { phisms (minor allele } \\
\text { frequency) }\end{array}$} & \multicolumn{2}{|c|}{$\begin{array}{l}\text { Patient number } \\
\text { Number of heart } \\
\text { valve operations }\end{array}$} & \multirow[t]{2}{*}{ p value } & \multirow[t]{2}{*}{ OR $(95 \% \mathrm{Cl})$} \\
\hline & 1 & $\geq 2$ & & \\
\hline \multicolumn{5}{|l|}{ IL 1B rs16944 (0.45) } \\
\hline$A A, A G$ & 65 & 15 & 0.510 & 1 \\
\hline GG & 25 & 8 & & $1.387(0.523-3.673)$ \\
\hline \multicolumn{5}{|l|}{ IL6 rs1800796 (0.26) } \\
\hline GG & 22 & 1 & 0.692 & 1 \\
\hline $\mathrm{GC}, \mathrm{CC}$ & 83 & 7 & & $1.855(0.217-15.886)$ \\
\hline \multicolumn{5}{|l|}{ IL10 rs1800871 (0.27) } \\
\hline $\mathrm{AA}, \mathrm{AG}$ & 79 & 22 & 0.466 & 1 \\
\hline GG & 9 & 1 & & $0.399(0.048-3.332)$ \\
\hline \multicolumn{5}{|l|}{ IL 10 rs1800896 (0.06) } \\
\hline $\mathrm{TT}, \mathrm{TC}$ & 88 & 23 & 0.205 & \\
\hline $\mathrm{CC}$ & 0 & 1 & & \\
\hline \multicolumn{5}{|l|}{ IFNG rs2430561 (0.08) } \\
\hline $\mathrm{AA}$ & 76 & 20 & 1.000 & 1 \\
\hline $\mathrm{AT}, \mathrm{TT}$ & 13 & 3 & & $0.877(0.228-3.378)$ \\
\hline \multicolumn{5}{|l|}{ TNFA rs1800629 (0.04) } \\
\hline $\mathrm{GG}$ & 80 & 23 & 0.471 & 1 \\
\hline $\mathrm{GA}, \mathrm{AA}$ & 9 & 1 & & $0.409(0.049-3.405)$ \\
\hline \multicolumn{5}{|l|}{ TGFB1 rs1800470 (0.46) } \\
\hline GG, GA & 20 & 10 & 0.043 & 1 \\
\hline $\mathrm{AA}$ & 69 & 13 & & $0.377(0.144-0.987)$ \\
\hline \multicolumn{5}{|l|}{ CRP rs1205 (0.40) } \\
\hline$C C, C T$ & 61 & 10 & 0.031 & 1 \\
\hline $\mathrm{TT}$ & 29 & 13 & & $2.734(1.073-6.969)$ \\
\hline
\end{tabular}

a Odds ratio was not calculated due to no patients in certain group

One of the main observations in this study was that reoperation was associated with inflammatory gene polymorphisms. Among the inflammatory mediators, CRP rs1205 was found to be associated with reoperation based on our final logistic regression model. Although SNPs of the other inflammatory mediator genes we tested were not statistically significant, we cannot exclude other genes from among the risk factors for reoperation, because allele frequencies can vary among ethnic groups, thus contributing to differences in outcomes.

Following the implantation of foreign material, acute and chronic inflammation can occur due to mediators such as interleukins, histamines, and growth factors. Moreover, inflammatory responses may affect the durability of prosthetic valves because thrombosis and degradation often occur in response to the activation and aggregation of platelets and inflammatory cells (Alavi et al. 2013). Many ongoing studies have explored the association between CRP genetic polymorphisms and 
their contribution to disease risk. One study found that the minor allele of the rs1205 CRP polymorphism could serve as a potential marker in identifying subjects prone to severe and heavily calcified aortic stenosis (Wypasek et al. 2015). Another study found that rs 1205 was associated with a decreased risk of cardiovascular mortality in Caucasians (Lange et al. 2006). On the other hand, a huge randomization meta-analysis conducted by Wensley and colleagues showed that CRP levels genetically determined by CRP polymorphisms including rs1205 are unrelated to risk for coronary heart disease (Wensley et al. 2011). These conflicting results are not surprising, because just as the distribution of $C R P$ alleles differs among races, disease risk also differs among races.

At present, the CRP rs1205 polymorphism is related to prosthetic valve dysfunction in Koreans patients who have undergone mechanical heart valve replacement, which presumably involves inflammatory responses. At this point, it is not easy to explain the mechanism underlying the observed association between the rs1205 polymorphism and heart valve reoperation. Previous researches reported that CRP, a biomarker of inflammation, was associated with valve stenosis which involves calcification and activation of local and systemic inflammation. CRP rs1205 mutation was associated with elevated CRP levels in patients with valve stenosis, suggesting inflammatory response and which can further be related with reoperation. Studies on the mechanism governing the contribution of rs1205 mutation to the need for reoperation remains to be determined.

The possible functionality of 3'-UTR rs1205 polymorphism affecting the reoperation could involve increased inflammatory cytokines. 3'-UTR mutations can affect mRNA stability of genes harboring them. The $3^{\prime}$-UTR of $C R P$ is quite long suggesting its special regulatory importance. A mechanism involving mRNA stability would be the effect on microRNA binding sites as $3^{\prime}$-UTR could be the main target leading to a change of post-transcriptional regulation of gene expression. Another possible option would be that rs1205 polymorphism influences CRP expression by its linkage disequilibrium with another functional genetic variant. The complex haplotypic relationships can functionally influence the effects of rs1205 mutation (Potaczek et al. 2012; Russell et al. 2004; Di Marco et al. 2001).

In the analysis of the subgroup of patients with mitral valve operation, TGFB1 rs1800470 was found to be statistically significant $(\mathrm{p}=0.043)$. One study suggested that the TGFB1 T29C (rs1800470) gene polymorphism could be associated with the risk of restenosis after coronary stent placement (Fragoso et al. 2015). This allele was previously associated with the risk of silent myocardial ischemia and acute coronary syndrome (Cruz et al.
2013; Syrris et al. 1998). Functional studies investigating the underlying mechanism revealed that the presence of the $\mathrm{T}$ allele produces a binding site for SF2/ASF proteins, which belong to the family of serine/arginine-rich (SR) proteins that regulate alternative splicing, suggesting that the TGFB1 T29C polymorphism could have a functional effect (Syrris et al. 1998; Sureau et al. 2001).

There are several limitations of this study. This is a retrospective study in a single center using a single ethnic group. Detailed inflammatory clinical phenotypes such as CRP levels or pathological findings could not be gathered.

\section{Conclusions}

In conclusion, this study is the first to demonstrate a relationship between inflammatory gene polymorphisms and heart valve reoperation. Genetic polymorphisms of $C R P$ rs1205 and TGFB1 rs1800470 were found to be factors influencing the need for reoperation, indicating the value of inflammatory gene variants as a possible marker for reoperation in patients who undergo prosthetic heart valve surgery. Given that this study was carried out at a single center and that the sample size was relatively small, our hypothesis requires further independent validation in multi-center studies with larger sample sizes of diverse ethnic groups.

\section{Abbreviations \\ CRP: C-reactive protein; IL1B: interleukin-1 beta; IL6: interleukin-6; IL 10: inter- leukin-10; INFG: interferon-gamma; INR: international normalized ratio; OR: odds ratio; SNP: single nucleotide polymorphism; TGFB1: transforming growth factor-beta-1; TNFA: tumor necrosis factor-alpha; TTR: time to therapeutic range.}

\section{Authors' contributions}

KEL, JHK, BCC and HSG made substantial contributions to conception and design of study. KEL, JHK, JEC, GYL, and YJC made acquisition and analysis of data. BCC and HSG made an interpretation of data. KEL, JHK, BCC, and HSG has been involved in drafting and revising the manuscript. All authors read and approved the final manuscript.

\section{Author details \\ ${ }^{1}$ College of Pharmacy, Chungbuk National University, Cheongju 28644, Korea. ${ }^{2}$ College of Pharmacy, Ajou University, Suwon 16499, Korea. ${ }^{3}$ Division of Life and Pharmaceutical Sciences, College of Pharmacy, Ewha Womans University, 11-1 Daehyun-Dong Seodaemun-Gu, Seoul 03760, Korea. ${ }^{4}$ Department of Thoracic and Cardiovascular Surgery, Yonsei University Medical Center, 50-1 Yonsei-Ro Seodaemun-Gu, Seoul 03722, Korea.}

\section{Acknowledgements}

This work was supported by a Grant from the National Research Foundation of Korea (NRF) funded by the Korean government (MSIP) (No. MRC, 2008-0062275).

\section{Competing interests}

The authors declare that they have no competing interests.

\section{Ethical approval}

All procedures followed were in accordance with the ethical standards of the responsible committee on human experimentation and with the Helsinki Declaration and its later amendments or comparable ethical standards. Informed consent was obtained from all patients for being included in the study. 
Received: 8 April 2016 Accepted: 12 June 2016

Published online: 30 June 2016

\section{References}

Alavi SH, Liu WF, Kheradvar A (2013) Inflammatory response assessment of a hybrid tissue-engineered heart valve leaflet. Ann Biomed Eng 41:316-326

Allama A, Ibrahim I, Abdallah A, Ashraf S, Youhana A, Kumar P, Bhatti F, Zaidi A (2013) Effect of body mass index on early clinical outcomes after cardiac surgery. Asian Cardiovasc Thorac Ann 22:667-673

Aydin E, Yapici F (2013) A retrospective analysis of factors influencing re-operation in patients undergoing mechanical valve replacement. Cardiovasc J Afr 24:251-254

Chan V, Malas T, Lapierre H, Boodhwani M, Lam B-K, Rubens FD, Hendry PJ, Masters RG, Goldstein W, Mesana TG (2011) Reoperation of left heart valve bioprostheses according to age at implantation. Circulation 124:S75-S80

Cohn LH, Aranki SF, Rizzo RJ, Adams DH, Cogswell KA, Kinchla NM, Couper GS, Collins JJ Jr (1993) Decrease in operative risk of reoperative valve surgery. Ann Thorac Surg 56:15-20

Cruz M, Fragoso JM, Alvarez-Leon E, Escobedo-de-la-Pena J, Valladares A Juarez-Cedillo T, Perez-Mendez O, Vargas-Alarcon G (2013) The TGF-B1 and IL-10 gene polymorphisms are associated with risk of developing silent myocardial ischemia in the diabetic patients. Immunol Lett 156:18-22

Di Marco S, Hel Z, Lachance C, Furneaux H, Radzioch D (2001) Polymorphism in the $3^{\prime}$-untranslated region of TNFalpha mRNA impairs binding of the post-transcriptional regulatory protein HuR to TNFalpha mRNA. Nucleic Acids Res 29:863-871

Fogarty AW, Glancy C, Jones S, Lewis SA, Mckeever TM, Britton JR (2008) A prospective study of weight change and systemic inflammation over $9 \mathrm{y}$. Am J Clin Nutr 87:30-35

Fragoso JM, Zuniga-Ramos J, Arellano-Gonzalez M, Alvarez-Leon E, VillegasTorres BE, Cruz-Lagunas A, Delgadillo-Rodriguez H, Pena-Duque MA, Martinez-Rios MA, Vargas-Alarcon G (2015) The T29C (rs1800470) polymorphism of the transforming growth factor-beta1 (TGF-beta1) gene is associated with restenosis after coronary stenting in Mexican patients. Exp Mol Pathol 98:13-17

Frank G, Tyers O, Eric Jamieson WR, lan Munro A, Germann E, Burr LH, Miyagishima RT, Ling H (1995) Reoperation in biological and mechanical valve populations: fate of the reoperative patient. Ann Thorac Surg 60:S464-S469

Garg PR, Saraswathy KN, Kalla AK, Sinha E, Ghosh PK (2013) Pro-inflammatory cytokine gene polymorphisms and threat for coronary heart disease in a North Indian Agrawal population. Gene 514:69-74

Helske S, Kupari M, Lindstedt KA, Kovanen PT (2007) Aortic valve stenosis: an active atheroinflammatory process. Curr Opin Lipidol 18:483-491

lacoviello L, Di Castelnuovo A, Gattone M, Pezzini A, Assanelli D, Lorenzet R, Del Zotto E, Colombo M, Napoleone E, Amore C, D'orazio A, Padovani A, de Gaetano G, Giannuzzi P, Donati MB (2005) Polymorphisms of the interleukin-1beta gene affect the risk of myocardial infarction and ischemic stroke at young age and the response of mononuclear cells to stimulation in vitro. Arterioscler Thromb Vasc Biol 25:222-227

Jones JM, O'kane H, Gladstone DJ, Sarsam MA, Campalani G, Macgowan SW, Cleland J, Cran GW (2001) Repeat heart valve surgery: risk factors for operative mortality. J Thorac Cardiovasc Surg 122:913-918

Khan SS, Trento A, Derobertis M, Kass RM, Sandhu M, Czer LS, Blanche C, Raissi S, Fontana GP, Cheng W, Chaux A, Matloff JM (2001) Twenty-year comparison of tissue and mechanical valve replacement. J Thorac Cardiovasc Surg 122:257-269

Lange LA, Carlson CS, Hindorff LA, Lange EM, Walston J, Durda JP, Cushman M, Bis JC, Zeng D, Lin D, Kuller LH, Nickerson DA, Psaty BM, Tracy RP, Reiner AP (2006) Association of polymorphisms in the CRP gene with circulating C-reactive protein levels and cardiovascular events. JAMA 296:2703-2711
Lytle BW, Cosgrove DM, Taylor PC, Gill CC, Goormastic M, Golding LR, Stewart RW, Loop FD (1986) Reoperations for valve surgery: perioperative mortality and determinants of risk for 1,000 patients, 1958-1984. Ann Thorac Surg 42:632-643

Nicklas BJ, Ambrosius W, Messier SP, Miller GD, Penninx BW, Loeser RF, Palla S, Bleecker E, Pahor M (2004) Diet-induced weight loss, exercise, and chronic inflammation in older, obese adults: a randomized controlled clinical trial. Am J Clin Nutr 79:544-551

Pibarot P, Dumesnil JG (2009) Prosthetic heart valves: selection of the optimal prosthesis and long-term management. Circulation 119:1034-1048

Piehler JM, Blackstone EH, Bailey KR, Sullivan ME, Pluth JR, Weiss NS, Brookmeyer RS, Chandler JG (1995) Reoperation on prosthetic heart values: patient-specific estimates of in-hospital events. J Thorac Cardiovasc Surg 109:30-48

Potaczek DP, Kamijo M, Hara M, Okumura K, Undas A, Nishiyama C (2012) A comparative search for human FcepsilonRlalpha gene (FCER1A) 3'-UTR polymorphisms in Japanese and Polish populations. Mol Biol Rep 39:3747-3753

Rahimtoola SH (2010) Choice of prosthetic heart valve in adults an update. J Am Coll Cardiol 55:2413-2426

Redberg RF, Schiller NB (2004) Gender and valvular surgery. J Thorac Cardiovasc Surg 127:1-3

Rizzoli G, Guglielmi C, Toscano G, Pistorio V, Vendramin I, Bottio T, Thiene G, Casarotto D (1999) Reoperations for acute prosthetic thrombosis and pannus: an assessment of rates, relationship and risk. Eur J Cardiothorac Surg 16:74-80

Russell Al, Cunninghame Graham DS, Shepherd C, Roberton CA, Whittaker J, Meeks J, Powell RJ, Isenberg DA, Walport MJ, Vyse TJ (2004) Polymorphism at the $C$-reactive protein locus influences gene expression and predisposes to systemic lupus erythematosus. Hum Mol Genet 13:137-147

Sinning JM, Scheer AC, Adenauer V, Ghanem A, Hammerstingl C, Schueler R, Müller C, Vasa-Nicotera M, Grube E, Nickenig G, Werner N (2012) Systemic inflammatory response syndrome predicts increased mortality in patients after transcatheter aortic valve implantation. Eur Heart J 33:1459-1468

Sureau A, Gattoni R, Dooghe Y, Stevenin J, Soret J (2001) SC35 autoregulates its expression by promoting splicing events that destabilize its mRNAs. EMBO J 20:1785-1796

Syrris P, Carter ND, Metcalfe JC, Kemp PR, Grainger DJ, Kaski JC, Crossman DC, Francis SE, Gunn J, Jeffery S, Heathcote K (1998) Transforming growth factor-beta1 gene polymorphisms and coronary artery disease. Clin Sci (Lond) 95:659-667

Wang K, Dong PS, Zhang HF, Li ZJ, Yang XM, Liu H (2015) Role of interleukin-6 gene polymorphisms in the risk of coronary artery disease. Genet $\mathrm{Mol}$ Res 14:3177-3183

Weerasinghe A, Edwards M-B, Taylor KM (1999) First redo heart valve replacement a 10-year analysis. Circulation 99:655-658

Wensley F, Gao P, Burgess S, Kaptoge S, Di Angelantonio E, Shah T, Engert JC, Clarke R, Davey-Smith G, Nordestgaard BG, Saleheen D, Samani NJ, Sandhu M, Anand S, Pepys MB, Smeeth L, Whittaker J, Casas JP, Thompson SG, Hingorani AD, Danesh J (2011) Association between C reactive protein and coronary heart disease: mendelian randomisation analysis based on individual participant data. BMJ 342:d548

White HD, Gruber M, Feyzi J, Kaatz S, Tse HF, Husted S, Albers GW (2007) Comparison of outcomes among patients randomized to warfarin therapy according to anticoagulant control: results from SPORTIF III and V. Arch Intern Med 167:239-245

Wypasek E, Potaczek DP, Undas A (2015) Association of the C-reactive protein gene (CRP) rs 1205 C > T polymorphism with aortic valve calcification in patients with aortic stenosis. Int J Mol Sci 16:23745-23759 